\title{
Chemical and Aroma Determination of the Pulp and Seeds of Murici (Byrsonima crassifolia L.)
}

\author{
Claudia M. Rezende* and Sandra R. G. Fraga \\ Instituto de Química, Universidade Federal do Rio de Janeiro, Centro de Tecnologia, Bloco A, Ilha do Fundão, \\ 21940-900 Rio de Janeiro - RJ, Brazil
}

\begin{abstract}
O murici (Byrsonima crassifolia L., Malpighiaceae) é uma pequena fruta tropical de intenso aroma frutal e semelhante a queijo rançoso. Aplicando a cromatografia gasosa de alta resoluçãoolfatometria acoplada a espectrometria de massas e usando técnica de diluição de aroma ("Aroma extract dilution analysis"), as substâncias de maior impacto no aroma do murici foram identificadas como sendo: butanoato de etila (frutal, doce), hexanoato de etila (frutal), 1-octeno-3-ol (odor semelhante a cogumelo), ácido butírico (queijo rançoso), ácido hexanóico (pungente, queijo) e 2-feniletanol (floral). A polpa da fruta é principalmente composta por ésteres etílicos, metílicos e feniletílicos, juntamente com ácidos carboxílicos, terpenos, $\delta$-lactonas e algumas substâncias sulfuradas. As sementes, que apresentaram um aroma semelhante ao de óleo rançoso, também lembrando queijo, tem como componentes majoritários os ácidos linoleico, oleico, esteárico e palmítico. Seu aroma foi associado aos ácidos butírico e hexanóico, ambos minoritários.
\end{abstract}

Murici (Byrsonima crassifolia L., Malpighiaceae), a small, tropical fruit, very popular in Brazil, has a strong fruity, rancid cheese aroma. High resolution gas chromatography-olfactometry-mass spectrometry and aroma extract dilution analysis identified the most potent substances in its aroma as ethyl butanoate (fruity, sweet), ethyl hexanoate (fruity), 1-octen-3-ol (mushroom like), butyric acid (rancid, cheese), hexanoic acid (pungent, cheese) and phenylethyl alcohol (floral). Its pulp is mainly composed of ethyl, methyl and phenylethyl esters and by carboxylic acids, terpenoids, $\delta$-lactones and some sulfur compounds. Seed analysis also showed a buttery and oily cheese aroma and GCMS revealed linoleic, oleic, stearic and palmitic acids as foremost components, while the aroma was associated to the butyric and hexanoic acids present in minor amounts.

Keywords: Byrsonima crassifolia L., Malpighiaceae, murici, volatile compounds, gas chromatography-olfactometry-mass spectrometry, aroma extract dilution analysis, seed composition

\section{Introduction}

In most Amazonian markets innumerous tropical forest plants are commercialized for medicinal and nutritive purposes. They are usually famous for their exotic aroma, taste, and succulent pulp.

The Amazonian fruit known as murici (Byrsonima crassifolia L., Malpighiaceae) grows on small trees (at the most $5 \mathrm{~m}$ tall) and may be found, from December to May, not only in the Amazonian region, but also in some Northeastern states of Brazil. When mature, it is yellow, has a diameter of 1.5 to $2 \mathrm{~cm}$, and a strong odor resembling a fruity, rancid cheese. Brazilian folklore records that its typical and intense flavor reminded the Portuguese explorers of their Alentejo cheese. The Indians used its

* e-mail: crezende@iq.ufrj.br juice in body paintings, in the treatment of respiratory diseases and as a laxative. ${ }^{1}$

Pharmacological studies, undertaken due to the ethnobotanical uses of its leaves and bark, showed bactericide, ${ }^{2}$ antifungal, ${ }^{3}$ spasmogenic ${ }^{4}$ and anti-protozoal ${ }^{5}$ activities, associated to triterpenes like betulinic acid and lupeol, sterols, flavonoids, like hyperin and quercetin, and a sulfonoglycolipid. ${ }^{6}$ Moreover, the flowers of Byrsonima crassifolia L., instead of nectar, have an abundant lipid composition whose major elements are mono and diglycerides and free carboxylic acids containing from 18 to 22 carbon atoms. ${ }^{7}$ Alves and Jennings investigated the volatiles of murici, showing 26 substances. Using GC-MS with a SE-30 wall-coated glass capillary column, ${ }^{8}$ they identified the major compounds as ethyl esters.

In an effort to extend our knowledge of such exotic but commercial Amazonian fruits, ${ }^{9,10}$ we report here the volatile composition of the pulp of murici (investigated by gas 
chromatography-olfactometry-mass spectrometry), and the most potent substances in its fruity, cheese-like aroma (determined by aroma extract dilution analysis, AEDA). ${ }^{11}$ The rancid cheese-like, oily aroma and the fatty acid composition of the seeds of murici were also investigated.

In the aroma research, dilution experiments were developed to serve as guides in the search for impact odorants. They function well in food matrices when compared to the relative odor potency of the components present, as it is common knowledge that only a few compounds may be responsible for the aroma of natural and processed foods. Due to its simplicity, AEDA is the most used dilution technique employed to distinguish between low and high threshold substances.

\section{Experimental}

\section{Plant material}

Ripe intact muricis (Byrsonima crassifolia L.) were purchased at Ver-o-Peso market (Belém, Pará, Brazil) and used after pulp and seed separation.

\section{Materials}

Ethyl esters, alcohols, ketones, aldehydes and carboxylic acids for co-injection were obtained from Aldrich (USA) and Merck (Germany). The methyl esters were obtained after diazomethane esterification. Terpenes, $\delta$-lactones and sulfur compounds were a gift from EMBRAPA (Rio de Janeiro, Brazil), Vittaflavor (São Paulo, Brazil) and Souza Cruz Research and Development Center (Rio de Janeiro).

\section{Analysis of the pulp}

Simultaneous distillation-extraction (SDE).Fresh murici pulp (250 g) was homogenized with $100 \mathrm{~mL}$ of distilled water in a blender. Dichloromethane $(50 \mathrm{~mL})$ was transferred into a pear-shaped flask and used as extracting solvent. The SDE apparatus head containing a water-cooled condenser $\left(0^{\circ} \mathrm{C}\right)$ was attached, connecting the distillation and extraction flasks. The organic extract obtained was dried over sodium sulfate, filtered and concentrated to $1 \mathrm{~mL}$. Under a gentle $\mathrm{N}_{2}$ stream, the SDE extract yielded $45 \mu \mathrm{g} \mathrm{kg}^{-1}$ (each of the three SDE analysis were performed in duplicate).

High resolution gas chromatography-olfactometrymass spectrometry (HRGC-O-MS). Pulp analyses were carried out using a HP 6890 gas chromatograph (Avondale PA, USA) equipped with a flame ionization detector (FID, $270{ }^{\circ} \mathrm{C}$ ) and a HP 6890 gas chromatograph (Avondale PA,
USA) coupled to a HP 5973 mass selective detector with $70 \mathrm{eV}$ for electron impact ionization $\left(280^{\circ} \mathrm{C}\right.$, MS scan range from m/z 40 to 750). A DB-Wax (Carbowax 20M, $\mathrm{J} \& \mathrm{~W})$ fused silica capillary column (30 m x $0.25 \mathrm{~mm} \times$ $0.25 \mu$ ) was used in both equipments with helium as carrier

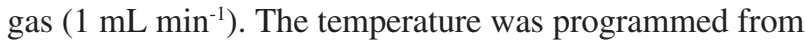
$40{ }^{\circ} \mathrm{C}$ (5 min) to $150{ }^{\circ} \mathrm{C}$ (at $5{ }^{\circ} \mathrm{C} \mathrm{min}^{-1}$ ), raised to $240{ }^{\circ} \mathrm{C}$ $\left(8{ }^{\circ} \mathrm{C} \mathrm{min}-1\right)$, and then held for $25 \mathrm{~min}$. At the end of the column, the effluent was split 1:10 (v/v) into the FID and $\mathrm{MS}$, and the sniffing port was held at $220^{\circ} \mathrm{C}$. The injector port (splitless mode, $1 \mathrm{~min}$ ) was at $240{ }^{\circ} \mathrm{C}$.

Seed analyses were performed in a DB-1 [100\% poli(dimethylsiloxane)] fused silica capillary column (30 $\mathrm{m} \times 0.25 \mathrm{~mm} \times 0.25 \mu$ ), the temperature being programmed from 40 to $290{ }^{\circ} \mathrm{C}\left(5^{\circ} \mathrm{C} \mathrm{min}{ }^{-1}\right.$; held for $\left.20 \mathrm{~min}\right)$ in both equipments.

All compounds were identified by comparison to the Wiley Mass spectral library (HP G1035A), by comparison of retention index data from the literature, ${ }^{12}$ calculated using $n$-alkanes chromatographed under the same conditions, and by injecting reference substances. Furthermore, their odor quality and intensity were used for comparison.

\section{Sensory studies}

Odor descriptions were obtained by a panel of 8 judges, trained on olfatory sensations to perceive and describe qualitative aspects of fruit aroma. Sniffing analyses were divided in periods of $10 \mathrm{~min}$, the panelists evaluating at intervals, during different sections. An odor description of each odorant was assigned. Odors detected by fewer than 5 panelists were classified as noise.

Aroma extract dilution analysis. $250 \mu \mathrm{L}$ of the SDE concentrated extract of murici was stepwise diluted (1:1) with dichloromethane. All diluted fractions were sniffed, after which the flavor dilution (FD) factors were obtained for each odorant in the extract.

\section{Analysis of seeds}

$25 \mathrm{~g}$ of murici seeds were crushed, macerated and extracted with dichloromethane for $2 \mathrm{~h}$ at ambient temperature, yielding $1.56 \mathrm{~g}$ of oil (Fraction A).

Another $25 \mathrm{~g}$ of seeds were macerated with chloroform/ methanol $(2: 1,200 \mathrm{~mL})$ filtrated and concentrated, then the contents were saponified ( $\mathrm{KOH} / \mathrm{ethanol}, 10 \% \mathrm{~m} / \mathrm{v})$ for $3 \mathrm{~h}$. The material was extracted with hexane $(3 \times 50 \mathrm{~mL})$ and the aqueous phase acidified with concentrated $\mathrm{HCl}$ ( $\mathrm{pH} 1-2)$, extracted with ethyl ether (3 x $50 \mathrm{~mL}$ ) and dried over anhydrous $\mathrm{MgSO}_{4}$ to give $0.52 \mathrm{~g}$ of saponified matter (Fraction B). 
Both fractions were esterified with a recently prepared diazomethane/ethyl ether solution and then analyzed by GC-FID and GC-MS.

\section{Results and Discussion}

The volatiles from murici pulp were investigated through a 15 min atmospheric pressure SDE extraction. ${ }^{13}$ Although this short SDE time gave low yields of extract, comparative sensorial evaluation with the pulp reported a natural and typical murici bouquet for the extract.

GC-MS, associated with co-injection with reference substances and retention indexes, revealed 95 substances, $50 \%$ of which were esters, $10.4 \%$ ketones and aldehydes, 9.4\% carboxylic acids, $8.3 \%$ terpenoids, $6.2 \%$ alcohols, $4.1 \%$ lactones, $4.1 \%$ sulfur compounds and $7.6 \%$ other substances (Figure 1). GC-FID on a Carbowax capillary column showed hexanoic, butyric and octanoic acids as major acidic compounds, as shown in Table 1. Ethyl esters prevailed in the composition, from $\mathrm{C} 4$ to $\mathrm{C} 18$, followed by their methyl analogs and free carboxylic acids. Furthermore, many phenylethyl derivatives were observed, together with other aromatic compounds. $\delta$-Lactones from $\mathrm{C} 8$ to $\mathrm{C} 11$ could also be observed. Their contribution was minor, but confirmed by co-injection with authentic samples, $\delta$-decalactone being the most important representative of the series.

The sulfur compounds observed in murici pulp were ethyl and methyl methylthiopropanoate and methionol. These substances have been associated with the enzymatic metabolism of methionine, and referred to as important odorants in pineapple, together with butanoates and unsaturated homologs. ${ }^{14,15}$ Today, it is a well-known fact that sulfur compounds strongly influence the olfactive perception of foods and beverages as flavors (coffee, garlic

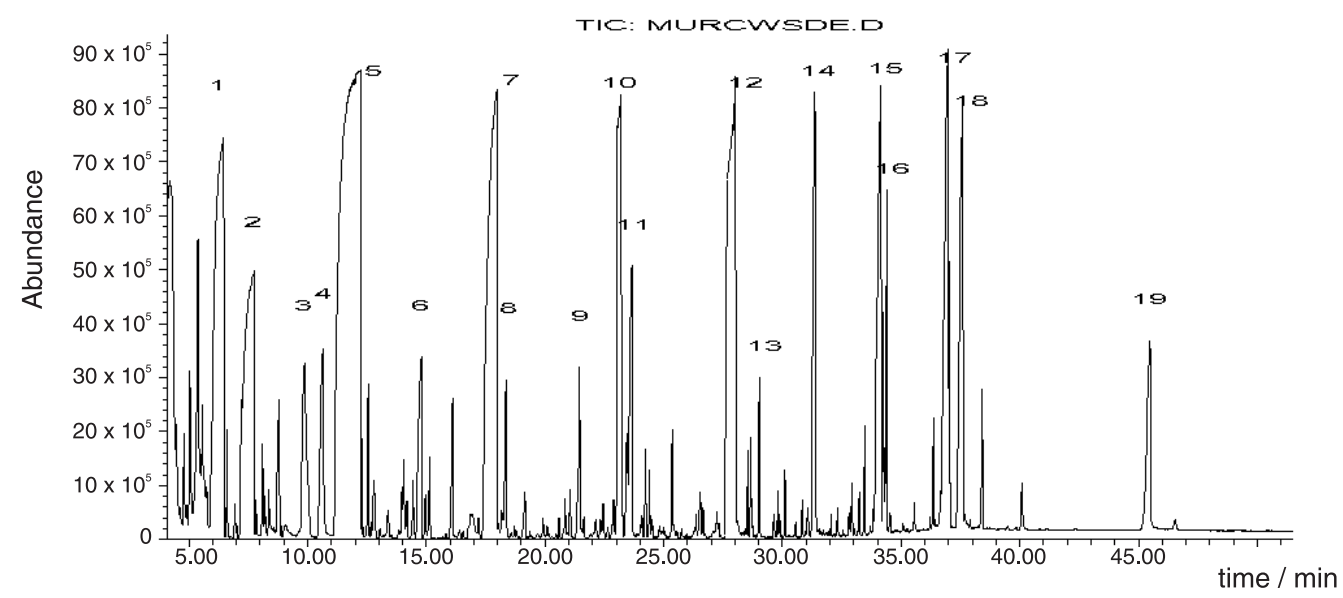

Figure 1. Total ion chromatogram of the SDE extract of murici (Byrsonima crassifolia L.) pulp, with the peak numbers corresponding to the identification of the compounds cited in Table 1.

Table 1. Volatile substances identified in the SDE extract of murici (Byrsonima crassifolia L.) pulp

\begin{tabular}{|c|c|c|c|c|}
\hline Peak number & Substance & Relative area (\%) & FD factor (odor description) & $\begin{array}{l}\text { Retention index } \\
\text { on DB-wax }\end{array}$ \\
\hline 1 & ethyl butanoate & 7.5 & 128(fruity, sweet) & 1026 \\
\hline 2 & 2-methyl-1-propanol & 3.8 & & 1108 \\
\hline 3 & methyl hexanoate & 2.1 & & 1177 \\
\hline 4 & 3-methyl-1-butanol & 1.4 & & 1185 \\
\hline 5 & ethyl hexanoate & 15.7 & 256 (fruity) & 1220 \\
\hline 6 & ethyl 2-hydroxypropanoate & 1.4 & & 1340 \\
\hline 7 & ethyl octanoate & 6.3 & & 1420 \\
\hline 8 & 1-octen-3-ol & 1.7 & 64(mushroom-like) & 1430 \\
\hline 9 & ethyl 3-methylthiopropanoate & 2.8 & & 1560 \\
\hline 10 & butanoic acid & 5.1 & 128(rancid, cheese-like) & 1628 \\
\hline 11 & ethyl decanoate & 3.9 & & 1633 \\
\hline 12 & hexanoic acid & 8.6 & 256(cheese-like) & 1849 \\
\hline 13 & phenethyl alcohol & 1.8 & 256 (floral) & 1901 \\
\hline 14 & octanoic acid & 3.5 & & 2050 \\
\hline 15 & ethyl hexadecanoate & 2.6 & & 2270 \\
\hline 16 & decanoic acid & 1.7 & & 2279 \\
\hline 17 & ethyl (Z)-9-octadecenoate & 4.4 & & 2470 \\
\hline 18 & methyl $(Z, Z)-9,12$-octadienoate & 2.7 & & 2488 \\
\hline 19 & hexadecanoic acid & 2.2 & & 3104 \\
\hline
\end{tabular}


and yellow passion fruit) or off-flavors (wines). ${ }^{16}$

Descriptive sensorial analysis of murici pointed to cheese-like, pungent, metallic, fruity and floral notes. In agreement with the sensorial evaluation of standards, GColfactometry using a sniffing port indicated methyl hexanoate and butanoic, hexanoic and octanoic acids as the most representative of the pungent, sour, cheese-like aroma observed. A metallic note was represented by ethyl 3-methylthiopropanoate with a sulfurous characteristic, as previously described. ${ }^{16}$ The intense fruity and floral notes could not be initially associated to any substance.

To achieve a better characterization of the most potent aroma substances of murici, aroma extract dilution analysis $(\mathrm{AEDA})^{11}$ was employed. In this technique, the results are expressed as flavor dilution (FD) factors: the ratio of the concentration of the odorant in the most concentrated extract to its concentration in the most diluted extract where the odor is still detected by HRGC-O. After AEDA, ethyl butanoate (fruity, sweet), ethyl hexanoate (fruity), 1octen-3-ol (mushroom-like) and phenylethyl alcohol (floral) were identified as the most potent odorants in the SDE extract, together with butanoic and hexanoic acids (pungent, cheese-like). The esters and alcohols contribute to aroma due to their low thresholds, ${ }^{17,18}$ while the contribution of higher threshold substances, as butanoic and hexanoic acids, could be explained by their much higher concentration in the fruit pulp.

Curiously, after the maceration of the small, woody and oily seed of murici, a buttery, rancid, oily aroma was detected, resembling the pulp odor. The GC-MS analysis of the diazomethane esterified dichloromethane extract of the seeds (Fraction A, Experimental) showed 31.1\% methyl hexadecanoate (palmitate), 29.8\% methyl (Z)-9-octadecenoate (oleate), $12.9 \%$ methyl (Z,Z)-9,12-octadienoate (linoleate), $3.8 \%$ methyl octadecanoate (stearate), $0.95 \%$ methyl (Z)-9-hexadecenoate (palmitoleate), $0.66 \%$ methyl tetradecanoate (myristate) and $0.42 \%$ methyl dodecanoate (laurate). A detailed investigation of the crude and nonesterified seed oil by GC-MS revealed the presence of minor quantities of butanoic and hexanoic acids (both less than $5 \%$ ), responsible for the similar rancid cheese-like aroma encounted in both seed and pulp. Saponification of the crude oil of murici (Fraction B) followed by diazomethane esterification showed methyl esters of palmitic $(5.5 \%)$, stearic $(6.3 \%)$, oleic $(53.3 \%)$ and linoleic $(34.9 \%)$ acids, while low molar mass esters were not observed.

In the seeds of cacao, butanoic and hexanoic acids were related to fermentation and drying, characterizing microbiological processes or oxidation, as typical degradation products. ${ }^{19,20}$ Here, the seeds of murici were worked up immediately after the fruit was opened. Aged murici seeds showed a reduction in oil content, while butanoic and hexanoic acids were not observed.

\section{Acknowledgements}

The authors thank CNPq, FAPERJ and CAPES for financial support and scholarships, and also Souza Cruz R\&D Centre and Vittaflavor Ind. Com. Ltda. for the gift of authentic standards.

\section{References}

1. Silva, S.; Frutas Brasil Frutas, Empresa das Artes Projetos \& Edições Artísticas Ltda: São Paulo, 1991.

2. Caceres, A.; Cano, O.; Samayoa, B.; Aguillar, L.; J. Ethnopharmacol. 1990, 30, 55.

3. Caceres, A.; Lopez, B.; Juarez, X.M.; del Agula, J.; Garcia, S.; J.Ethnopharmacol. 1993,40, 207.

4. Bejar, E.; Amarquaye, A.; Che, C.T.; Malone, M.H.; Fong, H.H.S.; Int. J. Pharmacog. 1995, 33, 25

5. Berger, I.; Barrientos, A.C.; Caceres, A.; Hernandez, M.; Rastrelli, L., Passreiter; C.M.; Kubelka, W.; J. Ethnopharmacol. 1998, 62, 107

6. Amarquaye, A.; Che, C.T.; Bejar, E.; Malone, M.H.; Harry, H.S.; Planta Med. 1994, 60, 85.

7. Vinson, S.B.; Williams, H.J.; Frankie, G.W.; Schrum, G.;. Biotropica 1997, 29, 76.

8. Alves, S.; Jennings, W.G.;. Food Chem. 1979, 4, 149.

9. Borges, E.S.; Rezende, C.M.;. J. Essent. Oil Res. 2000, 12, 71.

10. Franco, M.R.B.; Shibamoto, T.; J. Agric. Food Chem. 2000, 48, 1263.

11. Ullrich, F.; Grosch, W.; Z. Lebensm. Unters. Forsch. 1987, 184, 277.

12. Jennings, W.; Shibamoto, T.; Qualitative Analysis of Flavor and Fragrance Volatiles by Glass Capillary Gas Chromatography, Academic Press: New York, 1980.

13. Chaintreau, A.; Flavour Fragrance J. 2001, 16, 136.

14. Haagen-Smit, A.J.; Kirchner, J.G.; Deasy, C.L.; Prater, A.N.; J. Am. Chem. Soc. 1945, 67, 1651

15. Takeoka, G.R.; Buttery, R.G.; Teranishi, R.; Flath, R.A.; Gunter, M.; J. Agric. Food Chem. 1991, 39, 1848.

16. Mestres, M.; Busto, O.; Guasch, J.; J. Chromatogr. A 2000 , $881,569$.

17. Larsen, M.; Poll, L.; Z. Lebensm. Unters. Forsch. 1992, 195, 120.

18. Kubicková, J.; Grosch, W.; Int. Dairy J. 1998, 8, 17.

19. Lopez, A.S.; Quesnel, V.C.; J. Sci. Food Agric. 1973. 24, 319.

20. Ney, K.H.; Off Flavors in Foods and Beverages, Elsevier: Oxford, 1992.

Received: August 13, 2002

Published on the web: May 8, 2003 